Prepared in cooperation with the Metropolitan Council

\title{
Low-Flow Characteristics of the Mississippi River Upstream from the Twin Cities Metropolitan Area, Minnesota, 1932-2007
}

Scientific Investigations Report 2010-5163 



\section{Low-Flow Characteristics of the Mississippi River Upstream from the Twin Cities Metropolitan Area, Minnesota, 1932-2007}

By Erich Kessler and David L. Lorenz

Prepared in cooperation with the Metropolitan Council

Scientific Investigations Report 2010-5163 


\title{
U.S. Department of the Interior \\ KEN SALAZAR, Secretary \\ U.S. Geological Survey \\ Marcia K. McNutt, Director
}

\section{U.S. Geological Survey, Reston, Virginia: 2010}

\author{
For more information on the USGS — the Federal source for science about the Earth, its natural and living resources, \\ natural hazards, and the environment, visit http://www.usgs.gov or call 1-888-ASK-USGS \\ For an overview of USGS information products, including maps, imagery, and publications, \\ visit http://www.usgs.gov/pubprod \\ To order this and other USGS information products, visit http://store.usgs.gov
}

\begin{abstract}
Any use of trade, product, or firm names is for descriptive purposes only and does not imply endorsement by the U.S. Government.

Although this report is in the public domain, permission must be secured from the individual copyright owners to reproduce any copyrighted materials contained within this report.
\end{abstract}

Suggested citation:

Kessler, Erich, and Lorenz, D.L., 2010, Low-flow characteristics of the Mississippi River upstream from the Twin Cities Metropolitan Area, Minnesota, 1932-2007: U.S. Geological Survey Scientific Investigations Report 2010-5163, 14 p. 


\section{Contents}

Abstract
Introduction
Methods
$\quad$ Superposition of Flows
Measurens Among the Timing of Low Flows and Reservoir Elevations
$\quad$ Slow-Dunthetic Superposed Flow Statistics
Relations Among the Timing of Low-Flows and Reservoir Elevations
Implications of the Low-Flow Characteristics of the Mississippi River
Summary
References Cited.

\section{Figures}

1. Map showing location of study area and streamflow-gaging stations..............................

2-4. Graphs showing:

2. Example of superposed hydrographs for the Mississippi River near Anoka (station 05288500) for 1976 and 2003

3. Recession index values and regression line for the Mississippi River near Anoka, 1932-2007.....

4. Probability plot showing the synthetic superposed flows less than 700 cubic feet per second for the Mississippi River near Anoka .......................7

5. Map showing location of the low-flow water-surface profile

measurements with selected landmarks along the Mississippi River

6. Graph showing longitudinal profile of water-surface elevations along the Mississippi River with selected landmarks, October 8-9, 2008 , when flow ranged from 3,600 to 4,800 cubic feet per second (Mississippi River near Anoka, station 05288500)

\section{Tables}

1. Selected flow-duration statistics for Mississippi River near Anoka and four upstream streamflow-gaging stations for 1932-2007.

2. Number of occurrences of low flows (less than the 10th percentile) in the upper basin streams during low flows in the Mississippi River near Anoka by year for 1932-2007

3. Number of occurrences of low flows (less than the 10th percentile) in the upper basin streams during low flows in the Mississippi River near Anoka by month for 1932-2007. 
4. Number of occurrences of low-stage elevations for upper basin reservoirs during low flows in the Mississippi River near Anoka by year for 1960-2007.

5. Number of occurrences of low-stage elevations for upper basin reservoirs during low flows in the Mississippi River near Anoka by month for June-August 1960-2007

\section{Conversion Factors and Datums}

\begin{tabular}{|c|c|c|}
\hline Multiply & By & To obtain \\
\hline \multicolumn{3}{|c|}{ Length } \\
\hline foot $(\mathrm{ft})$ & 0.3048 & meter $(\mathrm{m})$ \\
\hline \multicolumn{3}{|c|}{ Flow rate } \\
\hline cubic foot per second $\left(\mathrm{ft}^{3} / \mathrm{s}\right)$ & 0.02832 & cubic meter per second $\left(\mathrm{m}^{3} / \mathrm{s}\right)$ \\
\hline
\end{tabular}

Vertical coordinate information is referenced to the North American Vertical Datum of 1988 (NAVD 88).

Horizontal coordinate information is referenced to the North American Datum of 1983 (NAD 83).

Elevation, as used in this report, refers to distance above the vertical datum. 


\title{
Low-Flow Characteristics of the Mississippi River Upstream from the Twin Cities Metropolitan Area, Minnesota, 1932-2007
}

\author{
By Erich Kessler and David L. Lorenz
}

\section{Abstract}

The U.S. Geological Survey, in cooperation with the Metropolitan Council, conducted a study to characterize regional low flows during 1932-2007 in the Mississippi River upstream from the Twin Cities metropolitan area in Minnesota and to describe the low-flow profile of the Mississippi River between the confluence of the Crow River and St. Anthony Falls. Probabilities of extremely low flow were estimated for the streamflow-gaging station (Mississippi River near Anoka) and the coincidence of low-flow periods, defined as the extended periods (at least 7 days) when all the daily flows were less than the 10th percentile of daily mean flows for the entire period of record, at four selected streamflow-gaging stations located upstream. The likelihood of extremely low flows was estimated by a superposition method for the Mississippi River near Anoka that created 5,776 synthetic hydrographs resulting in a minimum synthetic low flow of 398 cubic feet per second at a probability of occurrence of 0.0002 per year. Low-flow conditions at the Mississippi River near Anoka were associated with low-flow conditions at two or fewer of four upstream streamflow-gaging stations 42 percent of the time, indicating that sufficient water is available within the basin for many low flows and the occurrence of extremely low-flows is small. However, summer low-flow conditions at the Mississippi River near Anoka were almost always associated with low-stage elevations in three or more of the six upper basin reservoirs. A low-flow profile of the Mississippi River between the confluence of the Crow River and St. Anthony Falls was completed using a real-time kinematic global positioning system, and the water-surface profile was mapped during October 8-9, 2008, and annotated with local landmarks. This was done so that water-use planners could relate free-board elevations of selected water utility structures to the lowest flow conditions during 2008.

\section{Introduction}

Water-supply availability and planning are growing issues for the Twin Cities metropolitan area (TCMA) and other upstream municipalities on the Mississippi River in Minnesota. Currently (2009) about two-thirds of public supply water in the TCMA is obtained from groundwater, and about onethird is obtained from surface water (Metropolitan Council, 2007). Most TCMA suburbs obtain water from increasingly stressed (Metropolitan Council, 2007) groundwater sources, whereas the more densely populated cities of Minneapolis, St. Paul, and St. Cloud (located upstream from the TCMA) obtain all or most of their water from the Mississippi River. The Metropolitan Council is investigating the option of using surfacewater sources and in particular, the Mississippi River, to help provide future demand for water in the TCMA. It is uncertain how much more water could be withdrawn from the river during low-flow conditions and maintain a minimum threshold of sustained flow necessary for existing water withdrawal infrastructure and other uses including downstream navigation channels, sustainable habitat for fisheries and wildlife, recreation, and point source inflow dilution. Mississippi River water levels are maintained in the Minneapolis and St. Paul area through a complicated array of upstream reservoir water releases, downstream locks and dams, and natural flow in tributaries to the Mississippi River. Understanding current wateruse needs and water management/release practices on the Mississippi River and its tributaries during drought conditions are keys to understanding water availability in the TCMA.

The U.S. Geological Survey, in cooperation with the Metropolitan Council, conducted a study to characterize regional low flows from 1932 through 2007 in the Mississippi River Basin upstream from the TCMA in Minnesota, and to describe the water-surface profile of the Mississippi River between the confluence of the Crow River and St. Anthony Falls. Regional 
low-flow characterization and the water-surface profile can be used to plan for future demands of water supply.

This report documents the methodology and results of the regional low-flow characteristics and river surveying. To characterize regional low flow in the Mississippi River Basin upstream from the TCMA, probabilities of extreme low flow were estimated for the streamflow-gaging station on the Mississippi River near Anoka (station 05288500; fig. 1) and the coincidence of low flows at selected streamflow-gaging stations located upstream within the basin. The selected upstream streamflow-gaging stations (fig. 1) are the Mississippi River at Grand Rapids (station 05211000), Crow Wing River at Nimrod (station 05244000), Crow River at Rockford (station 05280000), and Rum River near St. Francis (station 05286000); hereinafter collectively referred to as the "upper basin streams." These streams were selected because they comprise the largest drainage areas of upstream subbasins, and provide the long-term historical data that are needed for this analysis. A water-surface profile of the Mississippi River was obtained between the confluence of the Crow River and St. Anthony Falls, where future water-supply infrastructure most likely would be located (fig. 1).

\section{Methods}

To characterize historical regional low flow and severity of regional drought conditions, daily-flow duration statistics were computed for selected streams using U.S. Geological Survey streamflow-gaging stations from 1932, which was the earliest year that all selected streamflow-gaging stations had flow records, to 2007 (U.S. Geological Survey, 2008). The Mississippi River near Anoka, located near the outlet of the study area, was selected as the base reference streamflowgaging station to which other stations are correlated. The flow in the Mississippi River near Anoka can fluctuate greatly diurnally and from day to day because of regulation by the Coon Rapids Dam and other upstream dams (fig. 1) generally associated with hydroelectric operations. These fluctuations in flow are not representative of the natural flow conditions. To better represent the natural flow conditions, a 7-day running mean using a quadratic smoothing operator (Wood and Hockens, 1970) was calculated for the daily flow values for all streamflow-gaging stations. The resulting 7-day running means were used in all of the analyses of daily-flow duration statistics within the study area.

\section{Superposition of Flows}

To assess the probability of extremely low flows of the Mississippi River near Anoka, the hydrographs of all observed summer to fall flows during the 76 years of the period of record (1932-2007) were superposed on each of the 76 observed spring peak flows to create a large set of synthetic hydrographs. From this dataset of 5,776 years of synthetic hydrographs, 76 years of summer-fall hydrographs superposed on 76 snowmelt peaks, the statistics of the range of minimum synthetic flows were computed.

The superposition is a permutation type analysis based on the laws of conditional probability analysis (Ott and Longnecker, 2001, chapter 4) that synthesizes potential summer-fall hydrographs by superposing observed summer-fall hydrographs on all observed spring snowmelt peak flows. The concept of superposed flows for the study area is shown in figure 2. The actual hydrograph for calendar year 2003 and the actual hydrograph for calendar year 1976 are used as an example that produced one of the 5,776 synthetic hydrographs for the study. The synthetic summer-fall hydrograph for 1976 is superposed on 2003 assuming the climatic conditions of 1976 had occurred after the snowmelt peak flow of 2003. The arrow shows the superposition of the 1976 spring snowmelt peak flow that occurred in April to the spring peak flow of 2003 that occurred in March; in this case, the 1976 spring snowmelt peak flow was superposed downward and backward in time (earlier) to match with the 2003 spring snowmelt peak flow. Similarly, the superposition translated the 433 cubic feet per second $\left(\mathrm{ft}^{3} / \mathrm{s}\right)$ flow increase during late May 1976 backward about 1 week in the synthetic flow hydrograph (fig. 2, inset).

To correctly represent the superposition of flows, the relation between flow and recession rate must be known. For example, if the expected daily decrease in flow is 1 percent at $5,000 \mathrm{ft}^{3} / \mathrm{s}$ and 2 percent at $50,000 \mathrm{ft}^{3} / \mathrm{s}$, then the synthetic decrease in daily flow values must be corrected when the flow at $50,000 \mathrm{ft}^{3} / \mathrm{s}$ is superposed to $5,000 \mathrm{ft}^{3} / \mathrm{s}$ to prevent the synthetic decrease from being unreasonably large. The recession rate generally is expressed as the index value in days per common log cycle rather than percent per day.

Rutledge (1998) described a computer program to estimate the rates of flow recessions. That program was modified to run in S-PLUS® (TIBCO Software, Inc., 2008). The program generates recession index values for all log-linear recessions longer than a specified duration. The specified duration used for this analysis was at least 10 days. For the Mississippi River near Anoka, 227 recessions were used to compute 


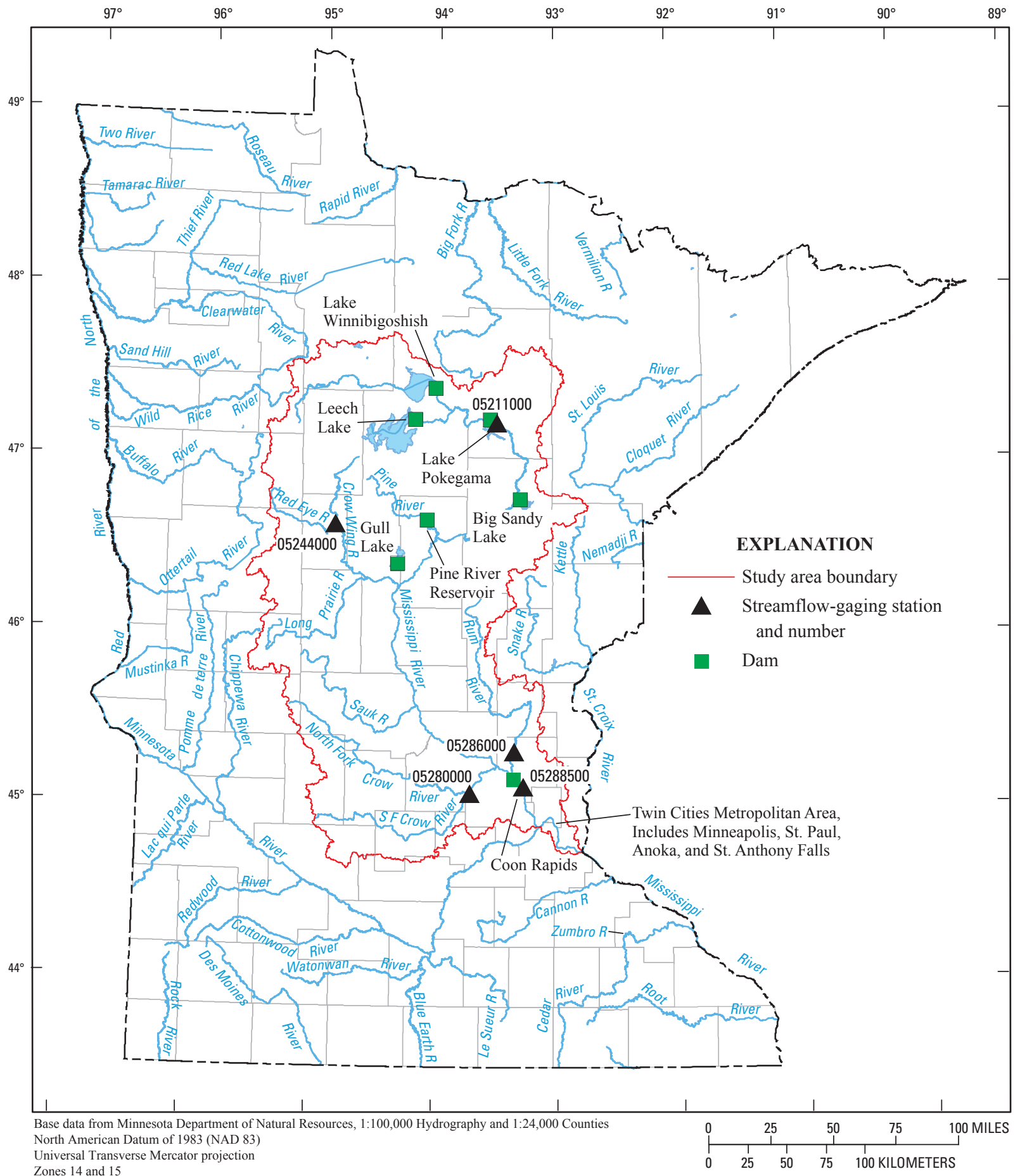

Figure 1. Location of study area and streamflow-gaging stations. 


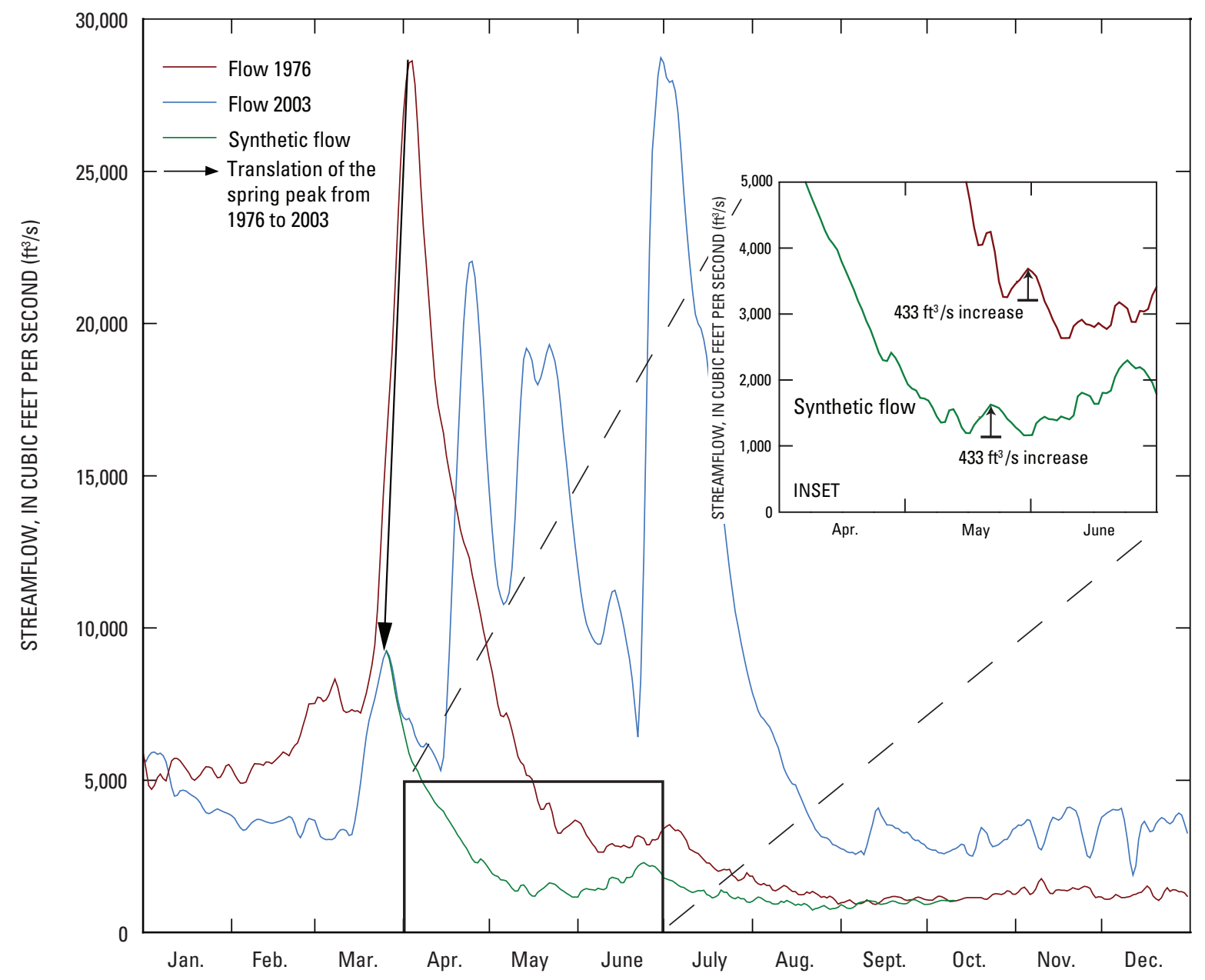

Figure 2. Example of superposed hydrographs for the Mississippi River near Anoka (station 05288500) for 1976 and 2003.

a master recession curve, which described the general recession rate for differing flow conditions and seasons. A linear regression analysis (Helsel and Hirsch, 2002) of the recession index values with flow and seasonal terms indicated that only season was a significant explanatory variable - the recession rate does not vary significantly by flow based on a 5-percent significance level.

The 76 years of flow record for the Mississippi River near Anoka were used to produce 5,776 years of synthetic hydrographs. The lowest synthetic superposed flow was determined from these data, along with a probability of occurrence. Probability occurrences for all flows less than $700 \mathrm{ft}^{3} / \mathrm{s}$ also were computed and plotted. For example, a 1 percent probability means that there is a 1 in 100 chance of occurrence in a given year. The analysis of the likelihood of extremely low flows provides an estimate of the likelihood of observing an extremely low flow in the future based on observed events in the past 76 years. The effects of any change in flow characteristics because of climate change are not accounted for in this analysis.

\section{Relations Among the Timing of Low Flows and Reservoir Elevations}

Reservoir elevation data were analyzed to assess the capacity to maintain flow in the Mississippi River by relating recent (since about 1960) reservoir capacity to low-flow conditions in the Mississippi River near Anoka. The year 1960 was chosen based on a review of reservoir levels indicating a change in reservoir management that has been consistent since then. In addition, daily elevation (stage) duration statistics were computed for the six headwaters reservoirs gaged by the U.S. Army Corps of Engineers (Gull Lake Reservoir, Leech Lake Dam and Reservoir, Pine River Dam and Reservoir, Lake Pokegama Dam and Reservoir, Big Sandy Lake and Reservoir, Lake Winnibigoshish Dam and Reservoir). The U.S. Army Corps of Engineers previously has studied reservoir releases in relation to travel times (U.S. Army Corps of Engineers, 2009). Relations between reservoir elevation data and Mississippi River flow were assumed to represent a consistent operating 
strategy during that period. No attempt was made to separately account for losses because of evapotranspiration.

A statistical comparison between flow of the Mississippi River near Anoka and elevations of the upper basin reservoirs also was made. Low flows for the Mississippi River near Anoka and elevations from the six upstream reservoirs were tabulated to determine how often and how many reservoirs were below the lower summer operating-limit elevation (U.S. Army Corps of Engineers, 2009).

To understand the patterns of low flows in the Mississippi River Basin upstream from Anoka, the co-occurrence of low flows near Anoka and low flows in the upper basin streams were tabulated. The low-flow periods were defined as the extended periods (at least 7 days) when all the daily flows were less than the 10th percentile of daily mean flows for the entire period of record. Low-flow periods that were separated by fewer than 10 days were combined into a single period. A percentile is a value on a scale of 100 that indicates the percent of a distribution that is equal to or below it. For example, streamflow at the 10th percentile is equal to or greater than 10 percent of streamflow recorded during all years that measurements have been made.

\section{Measurements for Water-Surface Profile of the Mississippi River}

The longitudinal profile of water-surface elevations along the Mississippi River between the confluence with the Crow River and St. Anthony Falls was surveyed during October of 2008 by using a real-time kinematic global positioning system (RTK-GPS) with a nominal vertical accuracy of 0.03 feet (ft) (Trimble, 2009). The water-surface profile data were collected on October 8-9, 2008, when flow rates ranged from 3,600 to $4,800 \mathrm{ft}^{3} / \mathrm{s}$, as recorded by the streamflow-gaging station Mississippi River near Anoka. The following projection parameters were used for this study: Universal Transverse Mercator (UTM) North Zone 15, North American Datum of 1983 (NAD 83), and Geoid g2003u03. These parameters were used based on the location of the survey and the time the survey was conducted. Water-surface elevations at many points along both sides of the river were collected to define the profile. The interval spacing used was a balance between maximizing the profile information of the river reach, while minimizing the likelihood that diurnal flow fluctuations and associated changes in river stage would adversely affect data collection efforts. The points were selected upstream and downstream from rapids and at reasonably spaced intervals (roughly $500 \mathrm{ft}$ ) through runs. In pools upstream from the dams at Coon Rapids and St. Anthony Falls, fewer elevation points were collected. RTK-GPS points were analyzed for accuracy by comparing them with base points located in the surrounding area. A few of the points were rated as poor because accuracy of $0.03 \mathrm{ft}$ could not be verified because the unit could not adequate radio link to the base station. This did not have a negative effect on the profile data because the points were located within the
Coon Rapids Dam pool, in which the slope is considered to be linear from the start of the pool to the Coon Rapids Dam. The elevation points of the Mississippi River were plotted relative to distance from the confluence with the Crow River and resulted in a longitudinal profile of the Mississippi River.

River profile data are useful for understanding the watersurface elevation in response to flow in the river. With additional cross-section information that is beyond the scope of this study, the data can be used for calibrating a water-surface profile model to estimate elevations at lower flow values.

\section{Low-Flow Characteristics of the Mississippi River}

Low-flow characteristics and statistics are presented in this section for the Mississippi River near Anoka, upper basin streams, and the six headwater reservoirs. Statistics are based on 5,776 years of synthetic flow record. The occurrences of low-flow periods between reservoirs and flow in the Mississippi River near Anoka were tabulated.

\section{Flow-Duration Statistics}

Selected flow-duration statistics for the Mississippi River near Anoka and the four upstream streamflow-gaging stations, based on daily-mean flow from 1932-2007, are presented in table 1. The minimum flow for the Mississippi River at Grand Rapids (station 05211000 ) was $0 \mathrm{ft}^{3} / \mathrm{s}$ on October 2, 1948. This is likely the result of flow regulation by the Pokegama Dam (at Lake Pokegama) because the average flow for the previous 5 days was $542 \mathrm{ft}^{3} / \mathrm{s}$. A visual inspection of the flow record for the Mississippi River at Grand Rapids and elevations at Pokegama Lake indicates a change in regulation at the dams beginning in about 1960, which resulted in a much reduced daily fluctuation in flow.

\section{Synthetic Superposed Flow Statistics}

A linear regression analysis of recession index values with flow and seasonal terms indicated that only the seasonal terms were significant and flow was not significant at the 5 -percent significance level. The following regression equation was determined for the log-transformed recession index:

$\widehat{\log (K)}=4.171-0.0993 \sin (2 \pi$ Dectime $)+0.2630 \cos (2 \pi$ Dectime $)(1)$

where

$K$ is the recession index value,

Dectime is the decimal part of the year,

$\log \quad$ is the natural logarithm, and

sin and $\cos$ are the sine and cosine functions. 
Table 1. Selected flow-duration statistics for Mississippi River near Anoka and four upstream streamflow-gaging stations for 1932-2007.

\begin{tabular}{lccc}
\hline \multirow{2}{*}{\multicolumn{1}{c}{ Station (number) }} & \multicolumn{3}{c}{$\begin{array}{c}\text { Daily mean streamflow, in cubic feet per second } \\
\text { based on data from 1932 to 2007 }\end{array}$} \\
\cline { 2 - 4 } & Minimum & 5th percentile & 10th percentile \\
\hline Mississippi River at Grand Rapids (05211000) & 10 & 199 & 287 \\
Crow Wing River at Nimrod (05244000) & 80.0 & 188 & 231 \\
Crow River at Rockford (05280000) & 3.80 & 28.0 & 40.0 \\
Rum River near St. Francis (05286000) & 30.0 & 100 & 123 \\
Mississippi River near Anoka (05288500) & 602 & 1,610 & 2,240 \\
\hline
\end{tabular}

${ }^{1}$ Result of regulation, the minimum streamflow since 1960 was 83 cubic feet per second.

The residual standard error of the linear regression was 0.3185 , the r-squared value (coefficient of determination) was 0.1493 , and the attained $p$-value was less than 0.0001 . The coefficients for the sine and cosine functions indicate a minimum recession index value of about 49 days per log cycle. This corresponds to a recession rate with the greatest slope of about 4.6 percent per day, which occurs in early June (fig. 3). A more typical recession index value of 60 days per log cycle, which occurs in late March and late August, corresponds to a recession rate of about 3.8 percent per day.

Calendar year data from 1932 to 2007 were used in the permutation analysis of synthetic hydrographs. The 76 years of record produced 5,776 years of synthetic hydrographs: 76 years of summer-fall hydrographs superposed on 76 snowmelt peaks. A correlation analysis (Helsel and Hirsch, 2002) between snowmelt peak flows and range of summer-fall flows was performed to determine whether or not permutations were reasonable. The correlation analysis indicated that there was not a strong relation between snowmelt peak flows and summer-fall flows, therefore no permutations were removed from the analysis. Because the recession rate does not vary as a function of flow rate and the shift in seasonal timing is small, no adjustments were made to the recession rate of the superposed flows. Flow rises that occurred in the actual record were transferred linearly into the superposed record to account for the actual increase in water in the system. For example, the $433 \mathrm{ft}^{3} / \mathrm{s}$ increase in measured flow during May 26-31, 1976

(fig. 2, inset) is maintained by the $433 \mathrm{ft}^{3} / \mathrm{s}$ increase in flow in the synthetic flow.

The probability distribution of synthetic superposed flows less than $700 \mathrm{ft}^{3} / \mathrm{s}$ are shown in figure 4 . Based on synthetic superposed hydrograph results, the lowest flow generated was $398 \mathrm{ft}^{3} / \mathrm{s}$. This corresponds to a probability of $0.0002(0.02$ percent) per year (fig. 4). The greatest risk for such an event is in the late spring to early summer after a dry winter. The probability that the flow in the Mississippi River near Anoka will be less than $660 \mathrm{ft}^{3} / \mathrm{s}$ in any 1 year is 1 percent and the probability that the flow will be less than $510 \mathrm{ft}^{3} / \mathrm{s}$ is 0.1 percent.

\section{Relations Among the Timing of Low-Flows and Reservoir Elevations}

Low flows (less than the 10th percentile) in the Mississippi River near Anoka were compared with low flows in the four upper basin streams, and with stage elevations from the six upstream reservoirs. Four tables were compiled summarizing the occurrences, defined by separate rises in flow, by year and by month. The number of occurrences of low flow in the upper basin streams during years when low flows occurred in the Mississippi River near Anoka is shown in table 2. These same occurrences are shown by month in table 3. Low-flow conditions in the Mississippi River near Anoka were associated with low-flow conditions at two or fewer of the four upper basin streams 42 percent of the time, indicating that for many low-flow scenarios sufficient water is available in the basin and that the occurrence of extremely low flows in the Mississippi River near Anoka is small.

Stage elevations of reservoirs were examined to determine how often they were below the summer lower operating levels for 1960-2007. The correlation between the number of occurrences of low-stage elevations in the upper basin reservoirs during years when low flows occurred in the Mississippi River near Anoka is shown in table 4. These same occurrences are shown by month, with the months spanning from June through August, in table 5. Fall through spring stage elevations were not used because of regulatory effects.

Drought severity can be determined from the tables by the number of occurrences of low flow or stage from the basins or reservoirs, respectively, and the Mississippi River near Anoka. For example, all four upper basins had six occurrences of low flow in 1934, whereas the Mississippi River near Anoka had 12 occurrences of low flow in that same year; in 2003, only the Mississippi River near Anoka had an occurrence of low flow. Thus, 1934 had more severe regional drought than 2003, when the flow in the tributaries was greater than the 10th percentile but the flow in the Mississippi River near Anoka was low. 


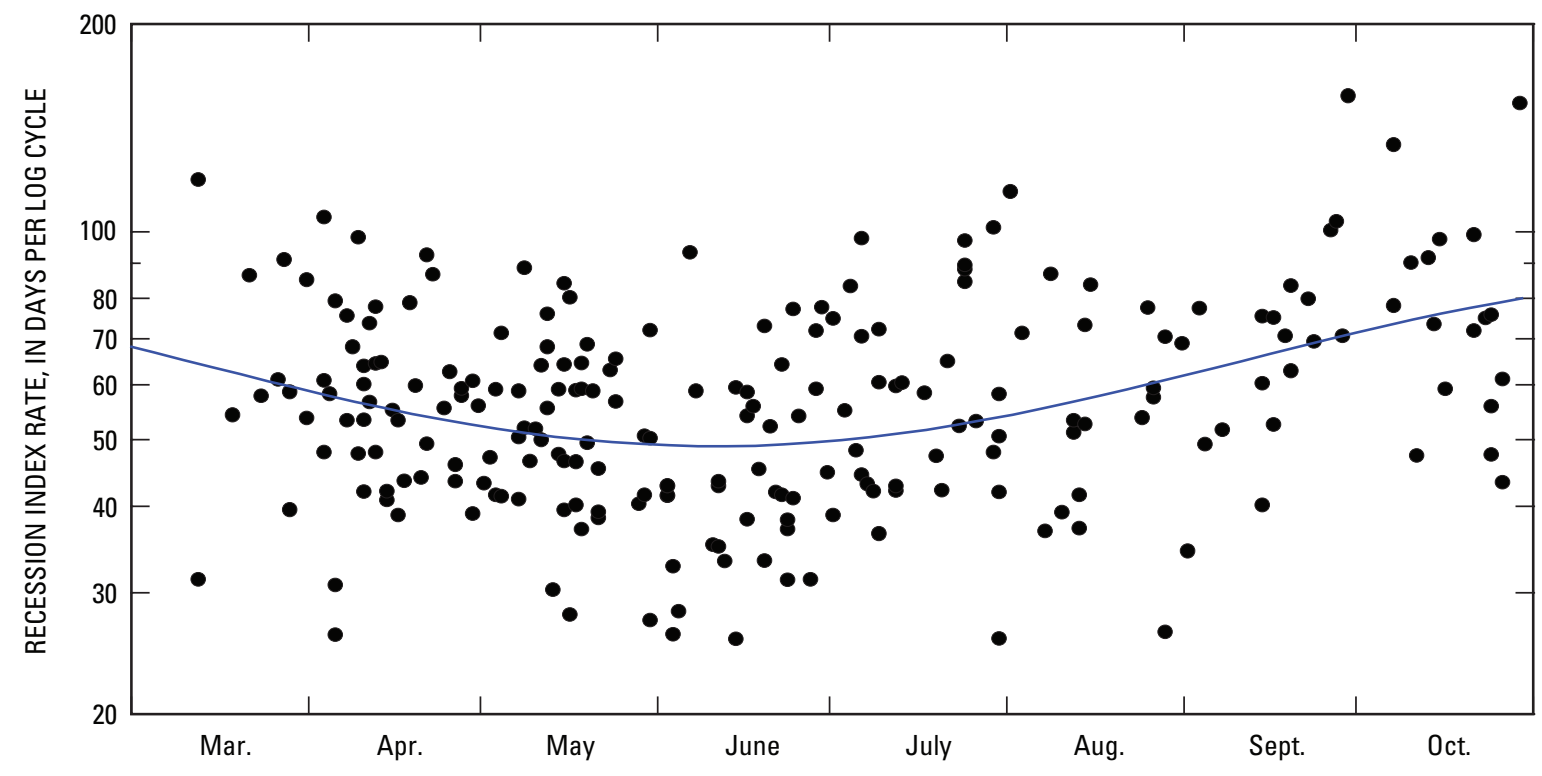

Figure 3. Recession index values and regression line for the Mississippi River near Anoka, 1932-2007.

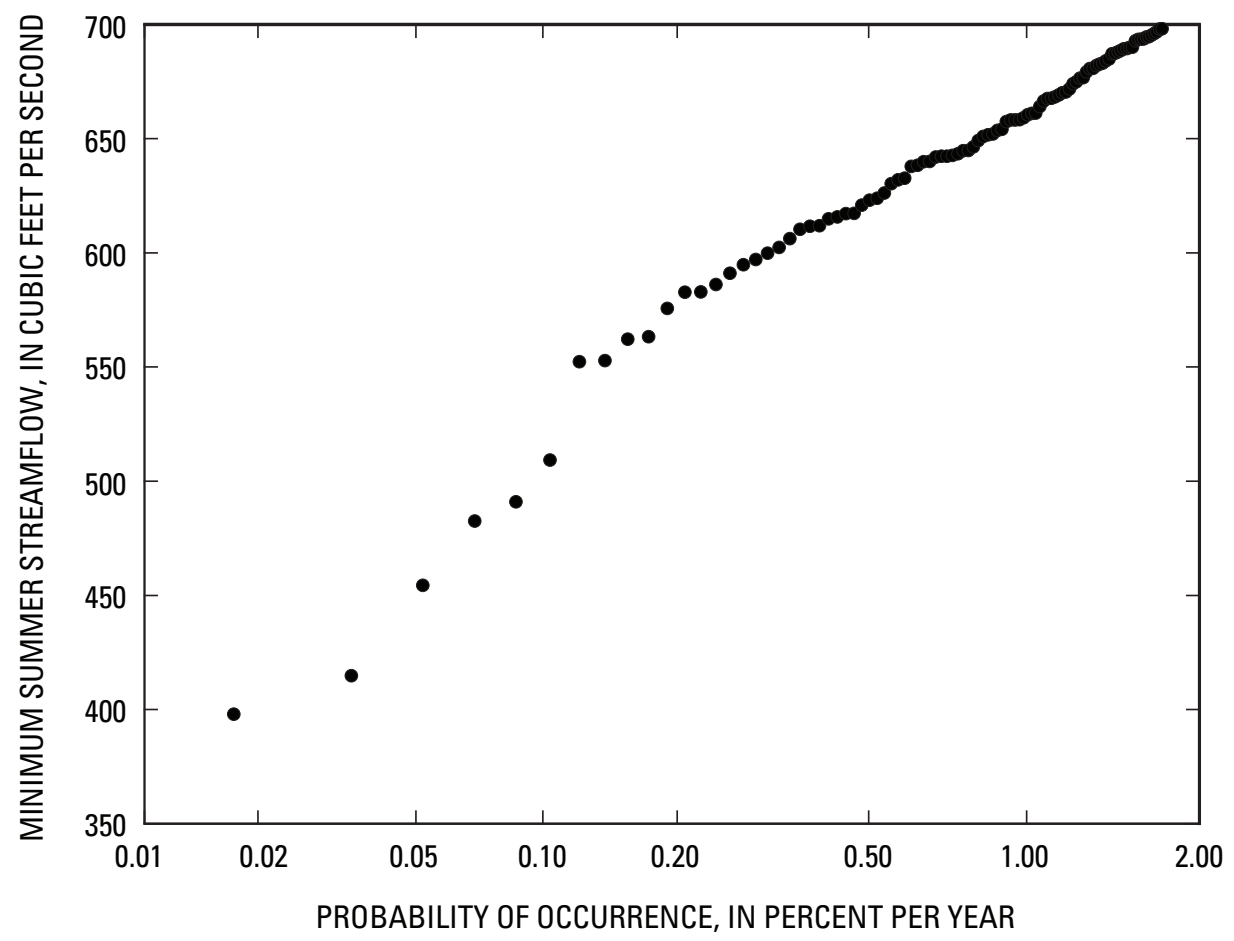

Figure 4. Probability plot showing the synthetic superposed flows less than 700 cubic feet per second for the Mississippi River near Anoka. 
Table 2. Number of occurrences of low flows (less than the 10th percentile) in the upper basin streams during low flows in the Mississippi River near Anoka by year for 1932-2007.

\begin{tabular}{|c|c|c|c|c|c|}
\hline \multirow{2}{*}{ Year $^{\mathrm{a}}$} & \multicolumn{5}{|c|}{ Number of upper basin streams ${ }^{b}$ that had low flow when low flow occurred near Anoka } \\
\hline & $0^{d}$ & 1 & 2 & 3 & 4 \\
\hline 1932 & 0 & 4 & 2 & 1 & 3 \\
\hline 1933 & 0 & 3 & 1 & 1 & 5 \\
\hline 1934 & 0 & 0 & 2 & 4 & 6 \\
\hline 1935 & 0 & 0 & 1 & 6 & 2 \\
\hline 1936 & 0 & 0 & 0 & 5 & 5 \\
\hline 1937 & 0 & 0 & 0 & 6 & 2 \\
\hline 1938 & 0 & 1 & 2 & 1 & 0 \\
\hline 1939 & 0 & 1 & 2 & 1 & 1 \\
\hline 1940 & 0 & 0 & 0 & 4 & 3 \\
\hline 1941 & 0 & 0 & 1 & 0 & 0 \\
\hline 1949 & 0 & 0 & 0 & 1 & 0 \\
\hline 1950 & 0 & 1 & 0 & 0 & 0 \\
\hline 1955 & 1 & 0 & 0 & 0 & 0 \\
\hline 1958 & 0 & 1 & 0 & 2 & 0 \\
\hline 1959 & 1 & 0 & 0 & 3 & 1 \\
\hline 1960 & 1 & 0 & 1 & 2 & 0 \\
\hline 1961 & 0 & 1 & 5 & 1 & 2 \\
\hline 1962 & 0 & 1 & 0 & 3 & 0 \\
\hline 1963 & 0 & 0 & 1 & 0 & 0 \\
\hline 1964 & 0 & 0 & 1 & 0 & 0 \\
\hline 1967 & 0 & 1 & 1 & 0 & 0 \\
\hline 1968 & 0 & 0 & 2 & 1 & 0 \\
\hline 1969 & 1 & 0 & 0 & 0 & 0 \\
\hline 1970 & 0 & 3 & 0 & 0 & 0 \\
\hline 1976 & 0 & 0 & 1 & 0 & 5 \\
\hline 1977 & 0 & 0 & 0 & 1 & 3 \\
\hline 1980 & 0 & 1 & 1 & 0 & 0 \\
\hline 1981 & 0 & 0 & 0 & 2 & 0 \\
\hline 1988 & 0 & 0 & 3 & 2 & 0 \\
\hline 1989 & 0 & 0 & 2 & 0 & 0 \\
\hline 1990 & 1 & 0 & 1 & 0 & 0 \\
\hline 2003 & 1 & 0 & 0 & 0 & 0 \\
\hline 2004 & 0 & 1 & 2 & 0 & 0 \\
\hline 2006 & 0 & 2 & 2 & 0 & 0 \\
\hline
\end{tabular}

${ }^{a}$ Only years for which flow of the Mississippi River near Anoka (station 05288500) was less than the 10th percentile are included.

bUpper basin streams are the Mississippi River at Grand Rapids (station 05211000), Crow Wing River at Nimrod (station 05244000), Crow River at Rockford (station 05280000), and Rum River near St. Francis (station 05286000).

${ }^{\mathrm{c}}$ Mississippi River near Anoka (station 05288500).

${ }^{\mathrm{d}}$ Values indicate number of occurrences of low flow near Anoka by year (less than 10th percentile of flow for at least 7 days). 
Table 3. Number of occurrences of low flows (less than the 10th percentile) in the upper basin streams during low flows in the Mississippi River near Anoka by month for 1932-2007.

\begin{tabular}{lccccc}
\hline \multirow{2}{*}{ Month } & \multicolumn{4}{c}{ Number of upper basin streams $^{\mathbf{a}}$ that had low flow when low flow occurred near Anoka } \\
\cline { 2 - 6 } & $\mathbf{0}^{\mathbf{c}}$ & $\mathbf{1}$ & $\mathbf{2}$ & $\mathbf{3}$ & $\mathbf{4}$ \\
\hline January & 0 & 3 & 3 & 8 & 2 \\
\hline February & 0 & 2 & 4 & 5 & 3 \\
\hline March & 0 & 2 & 3 & 7 & 1 \\
\hline April & 0 & 0 & 0 & 1 & 0 \\
May & 0 & 0 & 0 & 1 & 0 \\
\hline June & 0 & 0 & 3 & 2 & 1 \\
\hline July & 0 & 1 & 2 & 4 & 5 \\
August & 0 & 2 & 5 & 5 & 8 \\
\hline September & 1 & 1 & 4 & 3 & 6 \\
\hline October & 1 & 1 & 1 & 2 & 6 \\
\hline November & 2 & 4 & 2 & 4 & 4 \\
December & 2 & 5 & 7 & 5 & 2 \\
Total & $\mathbf{6}$ & $\mathbf{2 1}$ & $\mathbf{3 4}$ & $\mathbf{4 7}$ & $\mathbf{3 8}$ \\
\hline
\end{tabular}

${ }^{a}$ Upper basin streams are the Mississippi River at Grand Rapids (station 05211000), Crow Wing River at Nimrod (station 05244000), Crow River at Rockford (station 05280000), and Rum River near St. Francis (station 05286000).

${ }^{\mathrm{b}}$ Mississippi River near Anoka (station 05288500).

${ }^{c}$ Values indicate number of occurrences of low flow near Anoka during the month (less than 10th percentile of flow for at least 7 days).

Table 4. Number of occurrences of low-stage elevations for upper basin reservoirs during low flows in the Mississippi River near Anoka by year for 1960-2007.

\begin{tabular}{|c|c|c|c|c|c|}
\hline \multirow{2}{*}{ Year } & \multicolumn{5}{|c|}{ Number of upper basin reservoirs ${ }^{a}$ that were low ${ }^{b}$ when low flow occurred near Anoka } \\
\hline & 2 & 3 & 4 & 5 & 6 \\
\hline 1960 & 0 & 2 & 0 & 0 & 0 \\
\hline 1961 & 0 & 0 & 2 & 1 & 0 \\
\hline 1964 & 0 & 1 & 0 & 0 & 0 \\
\hline 1970 & 0 & 0 & 0 & 1 & 0 \\
\hline 1976 & 0 & 0 & 1 & 1 & 0 \\
\hline 1977 & 0 & 1 & 0 & 0 & 0 \\
\hline 1980 & 0 & 1 & 0 & 0 & 0 \\
\hline 1988 & 1 & 0 & 0 & 0 & 2 \\
\hline 1989 & 0 & 0 & 0 & 1 & 0 \\
\hline 2004 & 0 & 1 & 0 & 0 & 0 \\
\hline 2006 & 0 & 0 & 1 & 1 & 0 \\
\hline 2007 & 0 & 0 & 1 & 0 & 1 \\
\hline
\end{tabular}

${ }^{a}$ The upper basin reservoirs are Gull Lake Reservoir, Leech Lake Dam and Reservoir, Pine River Dam and Reservoir, Lake Pokegama Dam and Reservoir, Big Sandy Lake and Reservoir, Lake Winnibigoshish Dam and Reservoir.

${ }^{\text {b}}$ Low is defined as the stage elevation below the summer threshold from U.S. Army Corps of Engineers stage volume graphs available at $h t t p: / / w w w . m v p-w c . u s a c e . a r m y . m i l /$.

${ }^{\mathrm{c}}$ Mississippi River near Anoka (station 05288500). 
Table 5. Number of occurrences of low-stage elevations for upper basin reservoirs during low flows in the Mississippi River near Anoka by month for June-August 1960-2007.

\begin{tabular}{lccccc}
\hline \multirow{2}{*}{ Month } & \multicolumn{5}{c}{ Number of upper basin reservoirs $^{\text {a that }}$} \\
\cline { 2 - 6 } & $\mathbf{2}$ & $\mathbf{3}$ & $\mathbf{4}$ & $\mathbf{5}$ & $\mathbf{6}$ \\
\hline June & 1 & 0 & 1 & 0 & 0 \\
July & 0 & 1 & 4 & 0 & 1 \\
August & 0 & 5 & 0 & 5 & 2 \\
Total & $\mathbf{1}$ & $\mathbf{6}$ & $\mathbf{5}$ & $\mathbf{5}$ & $\mathbf{3}$ \\
\hline
\end{tabular}

${ }^{a}$ The upper basin reservoirs are Gull Lake Reservoir, Leech Lake Dam and Reservoir, Pine River Dam and Reservoir, Lake Pokegama Dam and Reservoir, Big Sandy Lake and Reservoir, Lake Winnibigoshish Dam and Reservoir.

${ }^{\mathrm{b}}$ Low is defined as the stage elevation below the summer threshold from U.S. Army Corps of Engineers stage volume graphs available at http://www.mvp-wc.usace.army.mil/.

'Mississippi River near Anoka (station 05288500).

The analysis of the upper basin streams indicates that they can be used as an indicator to whether or not the drought severity is regional or local. If all the upper basin streams have an occurrence of low flow and the Mississippi River near Anoka has an occurrence, the drought could be considered severe, with minimal rain in the basin for a long period. However, if the basin streams have no occurrence of low flow and the Mississippi River near Anoka does, the drought period would be less severe because rain events were occurring within the upper basins, but the events were not large enough to bring the Mississippi River near Anoka out of a low-flow condition.

Summer low-flow conditions at the Mississippi River near Anoka almost always were associated with low-stage elevations in 3 or more of the 6 upper basin reservoirs. Thus, flows through the reservoir are being maintained but little water is being held in reserve to sustain flow anywhere in the Mississippi River main stem.

\section{Water-Surface Profile of the Mississippi River}

Water-use planners want to relate free-board elevations of selected water utility structures to low-flow conditions. To do this, RTK-GPS was used to collect water-surface elevation data during October 8-9, 2008, along the Mississippi River from immediately downstream from the confluence of the Crow River to the upstream end of the pool created by St. Anthony Falls (fig. 5). The nominal vertical accuracy was $0.03 \mathrm{ft}$, confirmed by five observations at benchmarks. The actual vertical accuracy was affected by fluctuations in flow and wind effects, which may have resulted in small increases in elevation in subsequent downstream observations. The longitudinal profile of water-surface elevations collected along the banks of the Mississippi River and the selected landmarks is shown in figure 6. A large drop in elevation of the water-surface profile occurs at the Coon Rapids Dam. The total elevation drop from the Crow River to the upstream end of the pool created by St. Anthony Falls was $42 \mathrm{ft}$. The slope of the profile was steeper below the Coon Rapids Dam than above the dam.

\section{Implications of the Low-Flow Characteristics of the Mississippi River}

In contrast to historical record, which determined that the lowest daily flows occurred in late summer, the analysis of the synthetic hydrographs indicates that the greatest risk for extremely low flows in the Mississippi River near Anoka would occur in the late spring to early summer after a dry winter. This is likely because historical record has never experienced a dry late spring and early summer following a dry winter. Of the lowest 1 percent of the synthetic flows (58, corresponding to a flow of less than $660 \mathrm{ft}^{3} / \mathrm{s}$ ), 44 occurred before the end of June. All 44 had snowmelt peak flows of less than $11,300 \mathrm{ft}^{3} / \mathrm{s}$. There also is a risk for low flows anytime during the summer. Most of the lowest 3 percent of the synthetic flows, corresponding to a flow less than $779 \mathrm{ft}^{3} / \mathrm{s}$, occur after the end of June. Even though low snowmelt peak flows contribute to the likelihood of low seasonal flows, at least one synthetic seasonal low flow of less than $1,000 \mathrm{ft}^{3} / \mathrm{s}$ occurred after a snowmelt peak flow of $74,200 \mathrm{ft}^{3} / \mathrm{s}$.

The analysis of the relation between low flows in the Mississippi River near Anoka and upper basin streams 


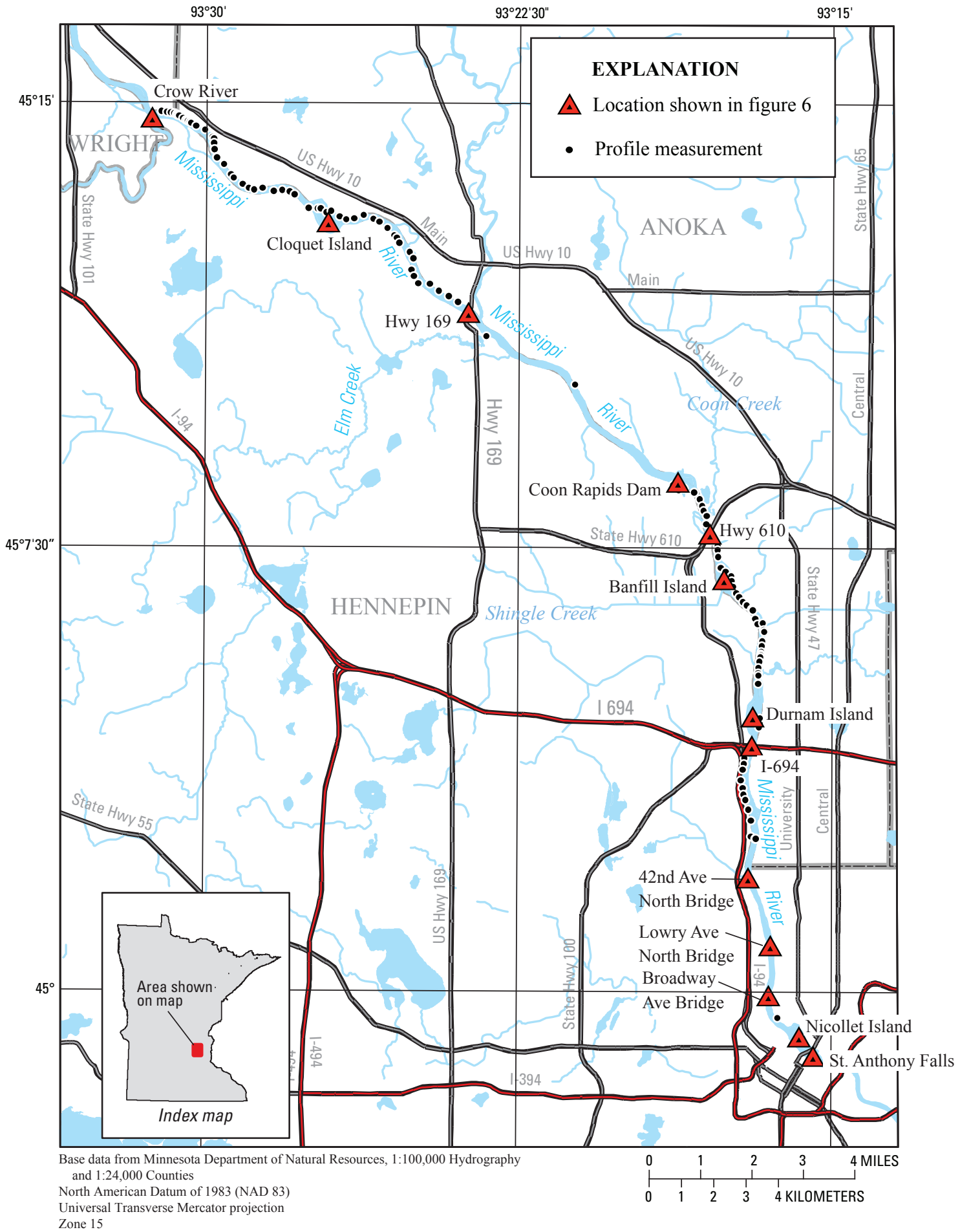

Figure 5. Location of the low-flow water-surface profile measurements with selected landmarks along the Mississippi River. 


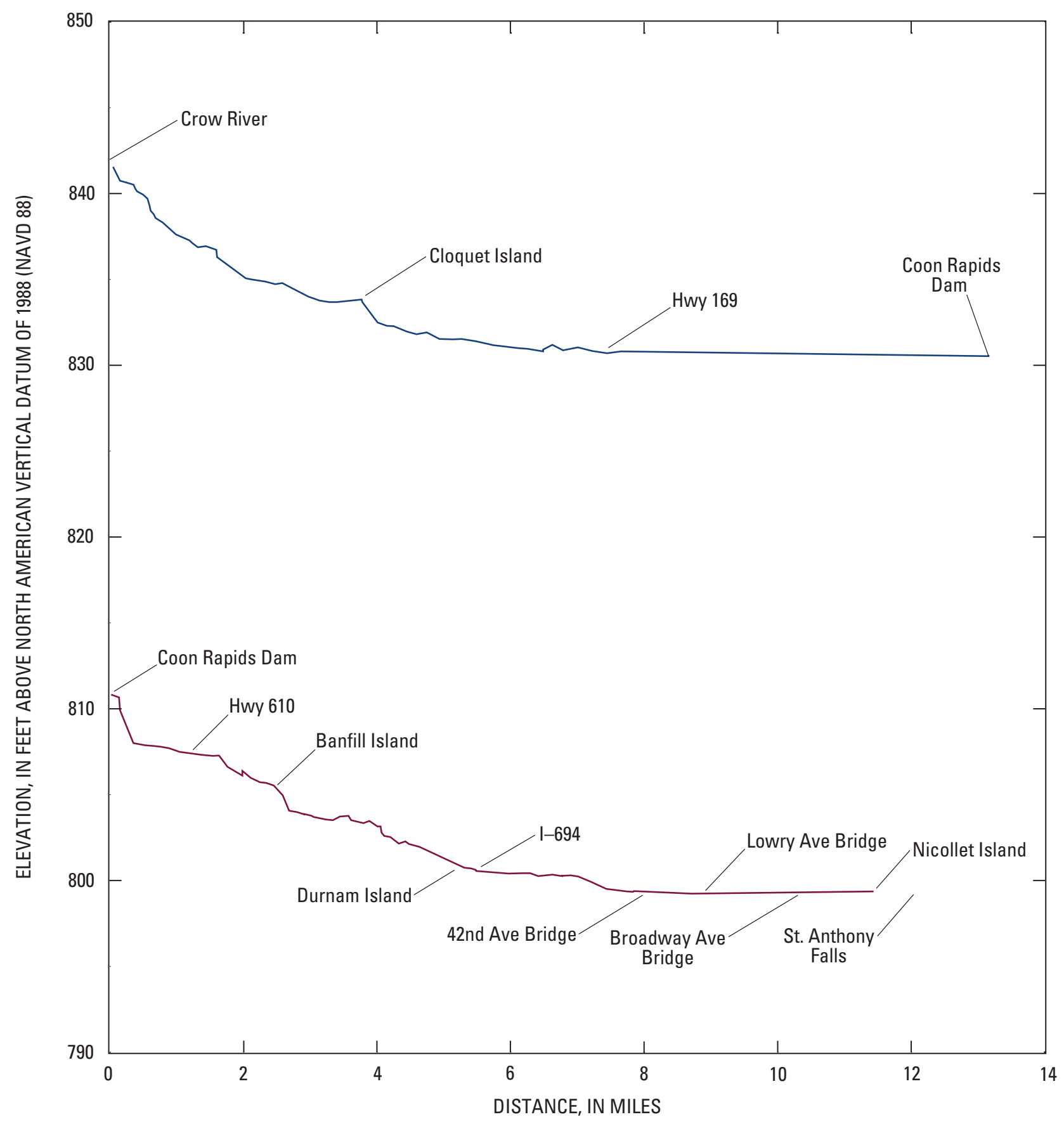

Figure 6. Longitudinal profile of water-surface elevations along the Mississippi River with selected landmarks, 0ctober 8-9, 2008, when flow ranged from 3,600 to 4,800 cubic feet per second (Mississippi River near Anoka, station 05288500). 
indicates that many times when the flow near Anoka is less than the 10th percentile, at least one upper basin stream has flow greater than the 10th percentile. This indicates that the risk for continued low flow in the Mississippi River near Anoka is lower when this occurs and that the flow in the upper basin streams needs to be monitored to assess the risk for continued low flow near Anoka.

The analysis of the relation between low flows in the Mississippi River near Anoka and the upper basin reservoirs indicates that many times when the flow near Anoka is less than the 10th percentile, most reservoir levels are below the summer operating limit elevation. This indicates that the flow through the reservoir is being maintained and that minimal water is held in reserve to sustain flow anywhere in the Mississippi River main stem.

\section{Summary}

Water-supply availability and planning are growing issues for the Twin Cities metropolitan area and other upstream municipalities on the Mississippi River in Minnesota. The U.S. Geological Survey, in cooperation with the Metropolitan Council, conducted a study to characterize regional low flows during 1932-2007 in the Mississippi River Basin upstream from the Twin Cities metropolitan area in Minnesota and to describe the low-flow profile of the Mississippi River between the confluence of the Crow River and St. Anthony Falls.

Probabilities of extreme low flow were estimated for the streamflow-gaging station on the Mississippi River near Anoka (station 05288500) and the coincidence of low-flows at four selected streamflow-gaging stations located upstream within the Mississippi River Basin. The likelihood of extremely low flows was estimated by a superposition method; 5,776 synthetic hydrographs were computed resulting in a minimum synthetic low flow of 398 cubic feet per second at a probability of occurrence of 0.0002 per year. The greatest risk for such an event is in the late spring to early summer after a dry winter. The likelihood of a low flow of 660 cubic feet per second or less in any one year in the Mississippi River near Anoka is 0.01 (1 percent) annually.

Low-flow conditions at the Mississippi River near Anoka, defined as the extended periods (at least 7 days) when all the daily flows were less than the 10th percentile of daily mean flows for the entire period of record, were associated with low-flow conditions at two or fewer of four upstream streamflow-gaging stations 42 percent of the time, indicating that sufficient water is available within the basin for many low-flow scenarios and the occurrence of extremely low flows is small. However, summer low-flow conditions at the Mississippi River near Anoka were almost always associated with low-stage elevations in three or more of the six upper basin reservoirs.

The analysis of the upper basin streams indicates that they can be used as an indicator to whether or not the drought severity is regional or local. If all the upper basin streams have an occurrence of low flow and the Mississippi River near Anoka has an occurrence of low flow, the drought could be considered severe, with minimal rain in the basin for a long period of time. However, if the upper basin streams have no occurrence of low flow and the Mississippi River near Anoka does, the drought period would be less severe because rain events were occurring within the basins, but the events were not large enough to bring the Mississippi River near Anoka out of a low-flow condition.

A water-surface profile of the Mississippi River between the confluence of the Crow River and St. Anthony Falls was completed using a real-time kinematic global positioning system. The water-surface profile was mapped and annotated with local landmarks. This was done so that water-use planners could relate free-board elevations of selected water utility structures to potential low-flow conditions. The data collected for the profile can be useful for low-flow water-surface profile models of the Mississippi River in that reach.

\section{References Cited}

Helsel, D.R., and Hirsch, R.M., 2002, Statistical methods in water resources: U.S. Geological Survey Techniques of Water-Resources Investigations, book 4, chap. A3, 522 p.

Metropolitan Council, 2007, Water supply planning in the Twin Cities metropolitan area-Report to the 2007 Minnesota State Legislature, accessed September 21, 2009, at http://www.metrocouncil.org/Environment/Watersupply/ documents/WaterSupplyReporttoLeg07_Final_web.pdf.

Ott, R.L., and Longnecker, M., 2001, An introduction to statistical methods and data analysis (5th ed.): Pacific Growth, Calif., Duxbury, 1,152 p.

Rutledge, A.T., 1998, Computer programs for describing the recession of ground-water discharge and estimating mean ground-water recharge and discharge from flow recordsUpdate: U.S. Geological Survey Water-Resources Investigations Report 98-4148, 43 p. (Also available at http://pubs. usgs.gov/wri/wri984148/.)

TIBCO Software, Inc., 2008, TIBCO Spotfire S+ 8.1 for Windows: Palo Alto, Calif., TIBCO Software, Inc., 572 p. 
Trimble, 2009, Trimble R4 GPS System Data Sheet, accessed August 16, 2010, at http://trl.trimble.com/docushare/ dsweb/Get/Document-468267/022543-490A_TrimbleR4_ DS_1109_LR.pdf.

U.S. Army Corps of Engineers, 2009, U.S. Army Corps of Engineers-St Paul District-Water Control Center, accessed May 13, 2009, at http://www.mvp-wc.usace.army.mil/.

U.S. Geological Survey, 2008, National Water Information System: U.S. Geological Survey Real-Time Data for USGS 05288500 Mississippi River near Anoka, Minnesota, accessed January 10, 2008, at http://waterdata.usgs.gov/mn/ nwis/uv/? site_no $=05288500$.

Wood, L.C., and Hockens, S.N., 1970, Least squares smoothing operators: Geophysics, v. 35, no. 6, p. 1,005-1,019.

Publishing support provided by:

Rolla and Denver Publishing Service Centers

For more information concerning this publication, contact:

Director, USGS Minnesota Water Science Center

2280 Woodale Drive

Mounds View, MN 55112

(763) 783-3100

Or visit the Minnesota Water Science Center Web site at: http://mn.water.usgs.gov 



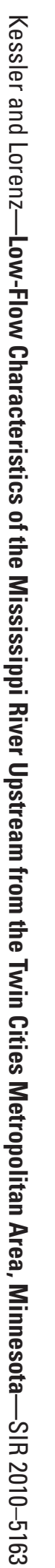

